\title{
SÓLON, FRAGMENTOS 20, 27, 34, $36^{1}$
}

\section{Fr. 20: Dísticos elegíacos}

Mas se vais ainda agora me escutar, tira isso fora

(sem te melindrar por meu melhor juízo), refaz o poema, Límpido-cantador, e canta assim:

"aos oitenta, o lote me atinja da morte". ${ }^{2}$

\section{Fr. 27: Dísticos elegíacos}

O filho impúbere, ainda infantil, cultiva e expulsa primeiro, em sete anos, o cerco dos dentes;

e quando então o deus leva a termo outros sete ciclos, sinais da nascente puberdade surgem.

$\mathrm{Na}$ terceira fase, o queixo (os membros em crescimento) cobre-se de pelos: flor da pele em troca.

$\mathrm{Na}$ quarta, em vigor qualquer um é, de longe, o melhor - no que os varões dão sinais de valor.

Na quinta, é tempo de o homem estar lembrado de casar e buscar gerar filhos pra adiante.

Na sexta, em tudo está sendo bem treinada a mente do homem e não quer mais atos tolos cometer.

Já na fase sete em mente e língua é o melhor, de longe, e na oito: as duas somam catorze anos.

Na nona, ainda é capaz; mas são, pra grande valor, mais lânguidas língua e sabedoria.

1 Tradução do texto grego: WEST, M. Iambi et Elegi Graeci ante Alexandrum Cantati. Oxford: The Clarendon Press, 1972. v. 2.

2 Cf. fragmento de Mimnermo (6W):

$\mathrm{Ah}$, que sem penosas preocupações e doenças, aos sessenta, o lote me atinja da morte.

West, em sua edição, coloca o último verso do fragmento de Mimnermo imediatamente antes do primeiro verso deste fragmento de Sólon. 
E se, completando a décima, alguém chegasse à medida, não sem tempo o lote teria da morte.

\section{Fr. 34: Tetrâmetros trocaicos}

Uns vieram atrás dos saques: tinham opulenta esperança

e pensavam, cada um deles, encontrar muita fortuna

- e que eu, macio no palavrório, revelaria mente áspera.

Mas foi poroso esse pensamento, e agora, encolerizados, me olham todos com olhar enviesado, como um adversário.

Não é preciso. As coisas que eu disse, com os deuses cumpri, mas outras, vãs, não realizei: não me agrada com a força

da tirania perpetrar algo, nem que, da rica terra da pátria, agora porção igual à dos maus os bons detenham.

\section{Fr. 36: Trímetros jâmbicos}

$\mathrm{Eu}$, dessas medidas com as quais juntei

o povo, sem atingir qual descansei?

Pode atestar, no julgamento do tempo, com excelência a mãe máxima dos numes olímpios, Terra negra, da qual um dia marcos tirei, por toda parte afixados: antes escravizada, agora liberta.

Muitos a Atenas, pátria criada por deuses, eu reconduzi, vendidos ora injusta, ora justamente - e outros que sob premente

dívida fugiram, sem mais falar língua ática, porque por toda parte errantes. Outros ainda, a ter aqui ultrajante servidão, com medo dos modos dos donos, pus libertos. Isso através do poder

- força e justiça ajustando, simultâneas realizei, e cumpri como prometera.

Normas igualmente para o bom e o mau 
(pra cada ajustando reto julgamento) redigi. Pegasse outro o aguilhão, como eu,

homem malpensante e de posses amante, não conteria o povo. Pois se eu quisera o que agradava então aos confrontadores, ou o que os outros pra eles planejavam, de muitos varões se privara esta pólis. Por isso, buscando apoio em toda parte, virei-me qual lobo entre muitas cadelas.

Tradução de ANDRÉ MALTA Faculdade de Filosofia, Letras e Ciências Humanas Universidade de São Paulo 